\title{
The Backpack Weights of Primary School Students and Their Backpack Use Status: Do We Need to Worry about It?
}

Tufan Aslı Sezer, Aslıhan Öztürk and Figen Işık Esenay Ankara University, Faculty of Nursing, Department of Nursing

\section{Abstract}

Improper backpack use can cause various health problems, such as lower back, back, and shoulder pain and postural distortion in children. These problems reduce the quality of life of children and affect their success in their educational lives. This study aimed to determine the weights of primary school students' backpack and their backpack use status. The results of this study offer a guide for the educational practitioners oriented at gaining positive behaviors by using the right backpack. This descriptive cross-sectional study was carried out in the fall semester of 2017. The sample comprised 374 students from three different schools in Ankara, aged 6-11. Data collection was done using a personal information form and checklist for backpack use, which was developed based on the related literature. The study used descriptive statistics, independent group $t$-test and one-way variance analysis (ANOVA) for data analysis. The mean backpack weight was $4.03 \mathrm{~kg}$. The study found that $96.2 \%$ of the children wore their backpacks using both shoulder straps, $54.2 \%$ of their backpacks were not in full contact with their backs, and $42.1 \%$ of the children wore their backpacks below their back and did not use a waist belt. The study determined the mean rate of the children's backpack weight to their body weight as $14.4 \%$. The study found that backpack weight increases in parallel with the child's age and grade. The study reported that backpack weights and improper backpack use among primary school students were high and most of the children carried backpacks that were heavier than 10\% of their body weight.

Key words: backpack; backpack weight; primary school children. 


\section{Introduction}

Primary school (6-10 years of age) is an important period for the body's development (Kellis \& Emmanouilidou, 2010). Children are obliged to carry various materials such as books, notebooks, folders, water bottles, lunch boxes, and additional clothes for gym class; therefore, they mostly use backpacks (Abdullah, McDonald, \& Jaberzadeh, 2012). Poor posture is a prominent problem that children and teens encounter due to backpacks. A number of studies have shown the significance of this issue (DrzalGrabiec, Truszczy'nska, Rykals, Rachwal, Snela, \& Podg'orska, 2014; Kalaiselvan, Kamalakannan, \& Sowmya, 2016; Paula, Silva, \& Silva, 2015; Rai \& Agarwal, 2014; Walicka-Cuprys, Skalska-Izdebska, Rachwab, \& Truszczynsks, 2015). Proper backpack use is important for the prevention of poor posture. If a child obliged to carry a backpack every day does not carry it properly, he/she may encounter various health problems, especially back, lower back, and shoulder pain (Dockrell, Simms, \& Blake, 2013; Drzal-Grabiec et al., 2014; Fernandes, Casarotto, \& Joao, 2008; Ibrahim, 2012; Kistner, Fiebert, Roach, \& Moore, 2013; Parlak-Demir, Çırak, Dalkılınç, Yılmaz, Uraş, \& Kömürcü, 2012; Zakeri, Baraz, Gheibizadeh, \& Saidkhani, 2016). A related study found that improper use of backpacks caused $44.6 \%, 21.3 \%$, and $63.4 \%$ of children to suffer back and lower back pain, kyphosis, and lordosis, respectively (Parlak-Demir et al., 2012). School-related factors, such as having a locker and the curriculum, and individual factors, such as the child's sex, age, having spinal distortion may increase the risk of experiencing backpack-related pain or postural distortion (Abdullah et al., 2012; Kellis \& Emmanouilidou, 2010; Rai \& Agarwal, 2014).

The American Occupational Therapy Association (AOTA) published a recommendations report with the aim of helping children to use backpacks properly to avoid health problems: (1) the weight of the child's backpack should not be heavier than $10 \%$ of his/her body weight; (2) backpacks should not be carried using only one strap; (3) shoulder straps and the back of backpacks should be filled with padding or viscoelastic fabric; (4) backpacks should be appropriate for the child's age; (5) shoulder straps should be adjusted to fit the child's back; (6) backpacks should be supported with a waist belt; (7) backpacks should fit the back; (8) items should be carried by hand or in a wheeled backpack if a backpack is too heavy (AOTA, 2013). However, the results of studies on the features of children's backpack carrying behavior and weights show that these were far from appropriate. Various studies have shown that children carry backpacks heavier than $10 \%$ of their body weight (Barkhordari, Ehrampoush, Barkhordari, Derakhshi, Barkhoradri, \& Mirzaii, 2013; Dockrell, Blake, \& Simms, 2016; Cuprys, et al., 2015; Kalaiselvan et al., 2016; Paula et al., 2012; Walicka- Zakeri et al., 2016). There has been no study about the features of backpack use and backpack weight in Turkey. This study aimed to fill this gap and to determine the backpack weights of Turkish primary school students and their backpack use status. This study is conceived to be a guide for educational practitioners to obtain positive behaviors related to backpack use among primary school children. 


\section{Methods \\ Research Design}

This cross-sectional descriptive study was carried out in three primary schools in Ankara in Turkey during the fall semester of 2017. The population of the study included all of the schools in Altindag, Ankara and the sample of the study comprised students from three schools chosen by basic random sampling from three sociodemographically stratified groups (low, medium, high). The sample size was determined as needing to be at least 374 by using the number of distinct individuals in population, which is known as sample size formula. Layers were determined according to children's grades: 1st, 2nd, 3rd, and 4th grades. Stratified random sampling sums were calculated using the "(layer name/layer size) $\mathrm{x}$ sample size" formula. The number of students from each layer to be included in the sample were determined according to the number of students in layers and layer size ( 83 students from the first grade, 93 from the second grade, 102 from the third grade, and 96 students from the fourth grade), and students in the layers were chosen with basic random sampling. The sample of the study included 374 students as a result of stratified s-sampling method. The study was carried out with volunteer students aged between six and 11 from the selected schools. The researchers obtained written informed consent from the participants' parents and verbal informed consent from the children themselves. Institutional authorization was obtained from the Altındag District Directorate of National Education and ethical approval to conduct this study (dated 12/25/2018 and numbered 82413) was received from the Ankara University Ethics Committee.

\section{Data Collection Tools}

The study used a personal information form which included eight items, and sought information about the age, sex, grade, body weight, backpack type, method of carrying, and backpack weight of the children, as well as a checklist which had eight items developed based on the recommendations of the American Academy of Pediatrics (AAP) (2015) and AOTA (2013) for proper backpack use. This form included items that determine the backpack features and child's backpack usage status, and the answers were assessed with "yes/no."

The researchers performed anthropometric measurements in accordance with the standard procedures set out in the Baby, Child, and Adolescent Monitoring Protocols of the Turkish Ministry of Health. The researchers measured the children's body weight using an electronic weight meter bascule (Jowoo-JW-3331) sensitive to $100 \mathrm{~g}$. The children were wearing their standard school uniform and were shoeless to standardize the measurements. The children's backpacks were weighed using a weighing machine sensitive to $10 \mathrm{~g}$. The same measurement tool was used for all to standardize the measurements and calibration was ensured every ten measurements. The rate of backpack weight to body weight was calculated using the ${ }^{\star} 100 /$ body weight formula. The researchers obtained data on backpack carrying features and usage of children by monitoring them. 


\section{Data Analysis}

The study used the Statistical Package for Social Sciences (SPSS) for Windows 15.0 package for the data coding and analysis. A p-value of $<0.05$ was set for statistical significance. The study used descriptive statistics (number, percentage, mean, standard deviation) for the analysis of items including the age, sex, grade, and backpack type, carrying type, weight, features, and use status. The researchers performed t-test and ANOVA in independent groups to determine change in backpack weight and backpack/body weight rate according to the sex, age, and grade of the children. Pearson correlation analysis determined the relationship between age and grade variables, and backpack weight.

\section{Results}

The mean age of the participating children was 8.33 years (min. 6, max. 11), their mean body weight was $29.3 \mathrm{~kg}$. Slightly more than half of the participants (53.9\%) were male. Backpack features and usage status are presented in Table 1, which shows that 96.2\% of the children carried their backpack using both of the straps, the backpacks of $54.2 \%$ were not fully in contact with their backs, $42.1 \%$ of them carried their backpacks dangling from their lower back, and none used a waist belt while carrying their backpack. None of the children had a locker at school to put their belongings in.

Table 1

Backpack use status ( $N=374)$

\begin{tabular}{|c|c|c|}
\hline \multirow{2}{*}{ The backpack use status of the child } & Yes & No \\
\hline & $\mathrm{N}(\%)$ & $\mathrm{N}(\%)$ \\
\hline There are two shoulder straps & $345(99.4)$ & $2(0.6)$ \\
\hline Shoulder straps are adjustable & $339(97.7)$ & $8(2.3)$ \\
\hline $\begin{array}{l}\text { Shoulder straps are large and supported with a pad or } \\
\text { viscoelastic fabric }\end{array}$ & $181(52.2)$ & $166(47.8)$ \\
\hline $\begin{array}{l}\text { The surface of the backpack contacting back is supported } \\
\text { with a pad or viscoelastic fabric }\end{array}$ & $176(50.7)$ & $171(49.3)$ \\
\hline There is waist or chest belt & - & $347(100.00)$ \\
\hline Child uses the waist or chest belt & - & $347(100.00)$ \\
\hline $\begin{array}{l}\text { Backpack was manufactured with light but long-wearing } \\
\text { material }\end{array}$ & $149(42.9)$ & $198(57.1)$ \\
\hline $\begin{array}{l}\text { Child carries the backpack by fastening it up } 5 \mathrm{~cm} \text { above the } \\
\text { middle back line with shoulder straps }\end{array}$ & $70(20.2)$ & $277(79.8)$ \\
\hline Child does not carry the backpack themselves & $27(7.21)$ & - \\
\hline Child has a locker at school & - & $374(100.00)$ \\
\hline
\end{tabular}

The mean backpack weight was $4.03 \mathrm{~kg}$ (min, $1.14 \mathrm{~kg}$, max, $8.11 \mathrm{~kg}$ ). The results show that the rate of backpack weight to body weight ranged between $3.94 \%$ and $31.13 \%$, with a mean value of $14.4 \%$ (Table 2). A large majority (83.6\%) of the children carried a backpack heavier than $10 \%$ of their body weight (see Figure 1). Backpack weight increased in parallel with the age $(r=0,233 ; \mathrm{p}<0.01)$ and grade $(r=0,333 ; \mathrm{p}<0.01)$ 
of the child $(\mathrm{p}<0.01)$. The backpack weight and backpack/body weight rate have not shown differences according to the gender of the children (Table 2).

Table 2

The distribution of backpack weight and percentage according to independent variables ( $N=374)$

\begin{tabular}{|c|c|c|c|c|c|c|}
\hline & \multicolumn{3}{|c|}{ Backpack weight } & \multicolumn{3}{|c|}{ Backpack/Body weight } \\
\hline & Mean $\pm S D$ & Min-max & $p$ & Mean $\pm S D$ & Min-max & $\mathrm{p}$ \\
\hline \multicolumn{7}{|l|}{ Sex } \\
\hline Female & $4.06 \pm 1.13$ & $1.57-8.11$ & \multirow{2}{*}{$t=0.273$} & $14.87 \pm 4.83$ & $4.92 \pm-31.13$ & \multirow[t]{2}{*}{$\mathrm{t}=1.838$} \\
\hline Male & $4.03 \pm 1.02$ & $1.14 \pm-7.28$ & & $13.98 \pm 4.24$ & $3.94 \pm-26.94$ & \\
\hline Total & $4.05 \pm 1.07$ & $1.14 \pm-8.11$ & $p=0.785$ & $14.45 \pm 4.50$ & $3.94 \pm-31.13$ & $p=0.067$ \\
\hline \multicolumn{7}{|l|}{ Grade } \\
\hline 1st grade ${ }^{\mathrm{a}}$ & $3.29 \pm 0.52$ & $2.23 \pm-4.69$ & \multirow{5}{*}{$\begin{array}{l}F=18.924 \\
p=0.000^{*}\end{array}$} & $14.69 \pm 3.36$ & $6.71 \pm-21.45$ & \multirow{5}{*}{$\begin{array}{l}F=3.015 \\
p=0.03^{*}\end{array}$} \\
\hline 2nd grade ${ }^{b}$ & $3.81 \pm 0.88$ & $1.14-5.89$ & & $14.43 \pm 3.98$ & $3.94 \pm-23.25$ & \\
\hline 3 rd grade ${ }^{c}$ & $4.37 \pm 1.13$ & $1.81 \pm 7.98$ & & $15.38 \pm 5.33$ & $5.26 \pm-31.13$ & \\
\hline 4 th grade $^{d}$ & $4.33 \pm 1.15$ & $1.96-8.11$ & & $13.57 \pm 4.50$ & $4.92-30.94$ & \\
\hline Total & $4.05 \pm 1.07$ & $1.14-8.11$ & & $14.45 \pm 4.50$ & $3.94-31.13$ & \\
\hline \multicolumn{7}{|l|}{ Age } \\
\hline 6 years olde & $3.31 \pm 0.54$ & $2.23-4.69$ & \multirow{7}{*}{$\begin{array}{l}F=10.067 \\
p=0.000^{*}\end{array}$} & $14.76 \pm 3.24$ & $7.21-21.45$ & \multirow{7}{*}{$\begin{array}{l}F=5.571 \\
p=0.000^{*}\end{array}$} \\
\hline 7 years old ${ }^{f}$ & $3.63 \pm 0.85$ & $1.57-5.86$ & & $14.53 \pm 4.17$ & $6.37-23.25$ & \\
\hline 8 years old ${ }^{g}$ & $4.32 \pm 1.12$ & $1.14-7.98$ & & $15.87 \pm 4.94$ & $3.94-31.13$ & \\
\hline 9 years old ${ }^{h}$ & $4.30 \pm 1.09$ & $1.81-6.98$ & & $14.38 \pm 4.51$ & $5.26-26.94$ & \\
\hline 10 years old & $4.19 \pm 1.10$ & $2.12-8.11$ & & $12.83 \pm 4.21$ & $4.92-30.94$ & \\
\hline 11 years old $j$ & $3.33 \pm 0.86$ & $2.06-4.60$ & & $9.19 \pm 2.92$ & $6.83-14.70$ & \\
\hline Total & $4.05 \pm 1.07$ & $1.14-8.11$ & & $14.45 \pm 4.50$ & $3.94-31.13$ & \\
\hline
\end{tabular}

ANOVA test; ${ }^{*}=\mathrm{p}<0.05$

Games Howel post hoc test was applied. Differences between classes groups a through b, $c, d(p<0.05)$ and $b$ through $c, d(p<0.05)$. Differences between age groups e through $g, h, i(p<0.05)$ and $f$ through $g, h, i(p<0.05)$, and $j$ through $e, f, g, h(p<0.05)$.

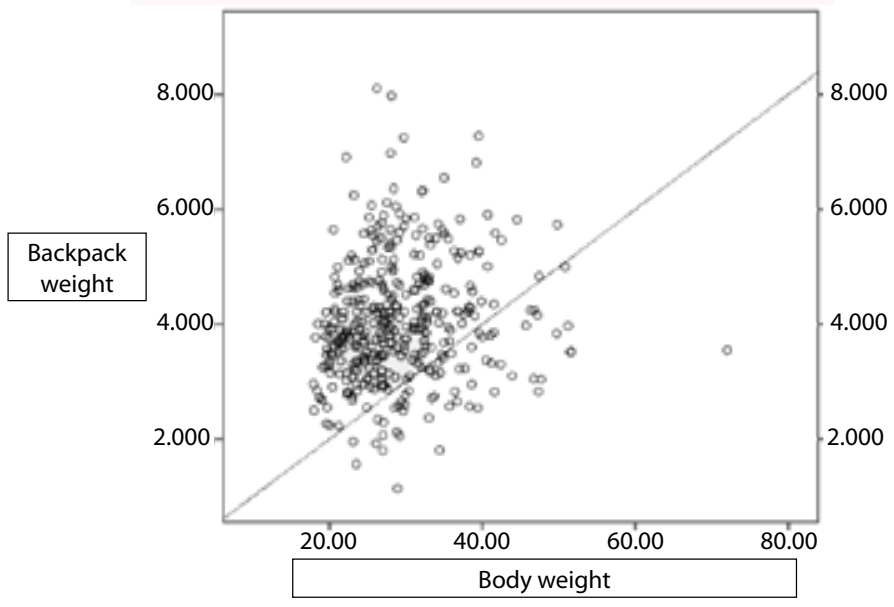

Figure 1. Mean backpack weight to body weight rate 


\section{Discussion}

This study found that the mean backpack weight of children aged between six and 11 was $4.03 \mathrm{~kg}$, the backpack/body weight rate was $14.4 \%$, and most of them carried backpacks heavier than $10 \%$ of their body weight. Similar results have been obtained in other studies conducted with primary school students (Barkhordari et al., 2013; Dockrell et al., 2016; Kellis \& Emmanouilidiou, 2010). Dockrell et al. (2016) found a mean backpack weight of $4.7 \mathrm{~kg}$ and identified the mean backpack/body weight rate as 12.4\%; Kellis and Emmanouilidiou (2010) found a backpack/body weight rate of $12.4 \%$ and Barkhordari et al. (2013) found a mean backpack weight of $4.6 \mathrm{~kg}$ and a backpack/body weight rate of 12.9\%. Zakeri et al. (2016) found that children's backpack weight was not standard. This study has also shown that the backpack/body weight rate of the children was quite high. One of the most significant reasons for this might be that most state-run-schools in Turkey do not have lockers for children to put their belongings in. Children are thus obliged to carry many books and notebooks daily in their backpacks. In addition, it is inevitable that children must carry heavy backpacks as they need other materials for classes (e.g. painting materials and extra clothing for gym class) and their lunch boxes.

The main standard for backpack use is the backpack/body weight rate rather than the backpack weight, which should be $10 \%$ at most (AOTA, 2013; AAP, 2015). Paula et al. (2015), Barkhordari et al. (2013), Zakeri et al. (2016), and Dockrell et al. (2016) found that $59.06 \%, 56.3 \%, 55.1 \%$, and $69.3 \%$, of primary school children carried backpacks weighing more than $10 \%$ of their body weight, and Walicka Cuprys et al. (2015) found that $59.63 \%$ of children aged seven carried backpacks weighing more than $10 \%$ of their body weight. Kalaiselvan et al. (2016) stated that most school children between the ages of 11 and 15 carried backpacks weighting between $10 \%$ and $18 \%$ of their body weight.

Various studies have found that children encounter back and shoulder pain (Ibrahim, 2012; Kistner et al., 2013; Paula et al., 2015) and postural distortions of the neck and back (Drzal-Grabiec et al., 2014; Kalaiselvan et al., 2016; Paula et al., 2015; Rai \& Agarwal, 2014), and that the prevalence of stooped shoulder, kyphosis, and lordosis has increased (Walicka-Cuprys et al., 2015; Zakeri et al., 2016), lordosis and the sacrum bent to an upright position (Kistner et al., 2013) as a result of children carrying backpacks heavier than $10 \%$ of their body weight. Reducing the weight which children carry daily, monitoring backpack weights, and providing lockers in schools may be beneficial to reduce these risks (Walicka-Cuprys et al., 2015).

Backpack carrying features are as important for children's physical development as backpack weight. The results show that children did not use a waist belt while carrying their backpack, that the backpacks of approximately half of the children were not fully in contact with their back, and they carried their backpack dangling below their lower backs. Parlak-Demir et al. (2012) found that $77.4 \%$ of children carried their backpacks with straps in a bilateral position and in full contact with their backs. Dockrell et al. 
(2016) stated that $85 \%$ of primary school children carried their backpacks on both shoulders. Barkhordari et al. (2013) reported that $83.4 \%$ of children carried their backpacks on both shoulders and only $4 \%$ used a wheeled backpack. Paula et al. (2015) found that the backpacks of $88.3 \%$ of children fully contacted their backs and only $6.33 \%$ used a waist belt. Kellis and Emmanouilidou (2010) stated that $89.3 \%$ of children between the ages of six and 11 carried their backpack on both shoulders, $6.9 \%$ used a wheeled backpack, and the rate of carrying backpacks on one shoulder increased in parallel with age. However, as the recommendations on proper backpack use state, not only should backpacks be carried on both shoulders but protective measures should also be taken, such as ensuring that backpacks contact the back fully, at the lower back level, and using a supportive waist belt (AAP, 2015; AOTA, 2013; Rai \& Agarwal, 2014). It is important that improper backpack use by children be determined, their backpack use should be monitored and education about this issue should be provided for parents and teachers.

This study determined that children's backpacks get heavier as their age and grade increase, in agreement with Barkhordari et al. (2013). The number of lessons increases as children move up through grades and accordingly the number of materials which children bring to school increases. However, while one study reported that backpack weight increased as age decreased (Paula et al., 2015), another reported that children between the ages of six and eight were five times more likely to carry heavier backpacks than older children (Kellis \& Emmanouilidou, 2010). The findings of the present study show that backpack carrying features differ in some ways from the findings of studies conducted in other countries. This is thought to be caused by the education system and by cultural and geographical differences. Education about proper backpack use should be designed in consideration of cultural elements and the main dynamics and values of the society in question in order to be effective.

This study found no statistically significant difference between the backpack/body weight rates of girls and boys. This result is in line with other studies in the literature (Ibrahim, 2012; Kellis \& Emmanouilidou, 2010; Paula et al., 2015). Girls carry the same materials as boys and their lower body weight increases the backpack/body weight rate.

\section{Conclusion}

This study was carried out to determine the backpack use features and backpack weights of primary school children. It found that the weight of children's backpacks and improper backpack use were high. The study also found that most of the child participants carried backpacks that were heavier than $10 \%$ of their body weight. The results show the necessity of taking precautions and organizing education regarding proper backpack use among children. The results also provide significant findings for the basis of protecting and improving children's health status, determining the needs and problems of primary school children, who represent a big part of the 
population pyramid of Turkey, and giving education and performing studies regarding these problems. Since school nurses take part in school health services effectively in many developed countries, they could also take part in all of these services in Turkey especially because school nurse practices are defined in the Nursing Regulation. However, school health services in Turkey are still not at the desired level and nurses are still not employed in schools. Nurses are necessary in schools to support and monitor the healthy development of primary school children, who represent most of the population of Turkey. School nurses can educate children, parents, and teachers about proper backpack use. They can also perform spine scans for the early diagnosis of pain and postural distortions which children encounter due to improper backpack use, and the development of distortions such as kyphosis, lordosis, and scoliosis can thus be prevented and reduced.

The provision of personal lockers at school may also reduce the weight of children's backpacks and allow them to avoid carrying unnecessary books. Adjustments can be made to protect children's physical health, such as making modifications to the school curriculum and weekly lesson schedule, arranging rational timetables to reduce the number of books and notebooks that children must carry to school every day.

Some limitations of the present study should be addressed. Firstly, the study was carried out with children from only three schools and secondly, backpack weight was measured just once. Future studies should include broader samples and measure backpack weight and backpack carrying duration several times.

\section{Acknowledgement}

The authors declare no conflicts of interest. The authors alone are responsible for the content and writing of the current paper.

\section{References}

Abdullah, A., McDonald, R., \& Jaberzadeh, S. (2012). The Effects of Backpack Load and Placement on Postural Deviation in Healthy Students: A Systematic Review. International Journal of Engineering Research and Applications, 2(6), 466-481.

American Academy of Pediatrics Backpack Safety (2015). Retrieved from https://www. healthychildren.org/English/safety-prevention/at-play/Pages/Backpack-Safety.aspx

American Occupational Therapy Association (2013). Backpack strategies for parents and students. Retrieved from http://www.aota.org//media/Corporate/Files/Backpack/ Backpack\%20Strategies\%20for\%20Parents\%20\%20Students.pdf 
Barkhordari, A., Ehrampoush, M.H., Barkhordari, M., Derakhshi, F., Barkhoradri, D. D. S., \& Mirzaii, M. (2013). Assessment of School Backpack Weight and Other Characteristics in Elementary Schools, Yazd, Iran. Journal of Community Health Research, 2(1), 2-7.

Dockrell, S., Blake, C., \& Simms, C. (2016). Guidelines for schoolbag carriage: an appraisal of safe load limits for schoolbag weight and duration of carriage. Work, 53,679-688. https:// doi.org/10.3233/WOR-162260

Dockrell, S., Simms, C., \& Blake, C. (2013). Schoolbag weight limit: can it be defined? Journal of School Health, 83(5), 368-77. https://doi.org/10.1111/josh.12040

Drzał-Grabiec, J., Truszczy'nska, A., Rykała, J., Rachwał, M., Snela, S., \& Podg'orska, J. (2014). Effect of asymmetrical backpack load on spinal curvature in school children. Work, 2, 383-388. https://doi.org/10.3233/WOR-141981

Fernandes, S. M. S., Casarotto, R. A., \& Joao, S. M. A. (2008). Effects of educational sessions on school backpack use among elementary school students. Brazilian Journal of Physical Therapy, 12(6), 447-53.

Ibrahim, A. H. (2012). Incidence of back pain in Egyptian school girls: Effect of schoolbag weight and carrying way. World Applied Sciences Journal, 17(11), 1526-1534. https://doi. org/10.1590/S1413-35552008005000002

Kalaiselvan, A., Kamalakannan, M., \& Sowmya, M. V. (2016). Effect of backpack of $10 \%$ of the body weight on cervical and shoulder posture for school going children. International Journal of Pharma and Bio Sciences, 7(4), 125-129. https://doi.org/10.22376/ ijpbs.2016.7.4.b125-129

Kellis, E., \& Emmanouilidou, M. (2010). The effects of age and gender on the weight and use of schoolbags. Pediatric Physical Therapy, 22, 17-25. https://doi.org/10.1097/ PEP.0b013e3181cbf852

Kistner, F., Fiebert, I., Roach, K., \& Moore, J. (2013). Postural compensations and subjective complaints due to backpack loads and wear time in school children. Pediatric Physical Therapy, 25, 15-24. https://doi.org/10.1097/PEP.0b013e31827ab2f7

Parlak-Demir, Y., Çırak, Y., Dalkılınç, M., Yılmaz, G. D., Uraş, İ., \& Kömürcü, M. (2012). The Habits of Carrying Bag, Computer Use and Posture in Primary School Children. Ankara Medical Journal, 12(4), 182-187.

Paula, A. J. F., Silva, J. C. P., \& Silva, J. C. R. P. S. (2015). The influence of load imposed by the backpack school in children and teens in Brazil. Procedia Manufacturing, 3, 5350-5357. https://doi.org/10.1016/j.promfg.2015.07.645

Rai, A., \& Agarwal, S. (2014). Assessing the Effect of Postural Discomfort on School Going Children Due to Heavy Backpacks. Journal of Ergonomics, 4, 4-11. https://doi. org/10.4172/2165-7556.S4-011

The Baby, Child, and Adolescent Monitoring Protocols of the Ministry of Health of the Republic of Turkey (2013). Retrieved from http://sbu.saglik.gov.tr/Ekutuphane/Yayin/420

Walicka-Cuprys, K., Skalska-Izdebska, R., Rachwab, M., \& Truszczynska, A. (2015). Influence of the Weight of a School Backpack on Spinal Curvature in the Sagittal Plane of Seven-Year-Old Children. BioMed Research International, 20, 6-18. https://doi. org/10.1155/2015/817913 
Zakeri, Y., Baraz, S., Gheibizadeh, M., \& Saidkhani, V. (2016). Relationship Between Backpack Weight and Prevalence of Lordosis, Kyphosis, Scoliosis and Dropped Shoulders in Elementary Students. International Journal of Pediatrics, 4(6), 1859-1866.

\section{Tufan Aslı Sezer}

Ankara University, Faculty of Nursing, Department of Nursing Aktas mh. Plevne cd. No:5, 06080, Ankara, Turkey tasezer@ankara.edu.tr

\section{Aslıhan Öztürk}

Ankara University, Faculty of Nursing, Department of Nursing Aktas mh. Plevne cd. No:5, 06080, Ankara, Turkey Aslihan.Ozturk@ankara.edu.tr

Figen Işık Esenay

Ankara University, Faculty of Nursing, Department of Nursing Aktas mh. Plevne cd. No:5, 06080, Ankara, Turkey fesenay@yahoo.com 


\section{Težina ruksaka i načini nošenja ruksaka učenika u osnovnoj školi: Trebamo li biti zabrinuti?}

\section{Sažetak}

Nepravilno nošenje školske torbe, točnije ruksaka u djece može uzrokovati različite zdravstvene probleme kao što su bolovi u donjem dijelu leđa, u leđima, u ramenima $i$ iskrivljeno držanje. Ti problemi smanjuju kvalitetu života djece $i$ utječu na njihov uspjeh u obrazovanju. Cilj je ovoga istraživanja odrediti težinu ruksaka i način na koji učenici nose torbe. Rezultati ovoga istraživanja nude smjernice za donošenje pozitivnih postupaka kod nošenja dobre torbe. Ovo deskriptivno, transverzalno istraživanje, provedeno je u jesen 2017. godine. Uzorak su činila 374 učenika iz tri različite škole u Ankari u dobi od 6 do 11 godina. Podaci su prikupljeni koristeći se obrascem za osobne informacije i kontrolnim listom za nošenje ruksaka koji je nastao oslanjajući se na povezanu literaturu. Za obradu podataka u istraživanju koristili su se deskriptivna statistika, nezavisni grupni t-test i jednosmjerna analiza varijance (ANOVA). Srednja vrijednost težine ruksaka bila je 4,03 kg. Istraživanje je pokazalo da 96,2 \% djece nosi ruksak koristeći se objema naramenicama, a 42,1\% djece nosi školsku torbu ispod leđa i ne upotrebljava pojas oko struka. Istraživanjem je određeno da je omjer srednje vrijednosti školske torbe u odnosu na učeničku tjelesnu težinu 14,4\%. Također se pokazalo da se težina ruksaka povećava s djetetovom dobi i razredom. Istraživanje je pokazalo da su težina ruksaka i nepravilno nošenje ruksaka prilično visoki među učenicima osnovne škole i da većina učenika nosi ruksak koji je teži od 10 \% njihove tjelesne težine.

Ključne riječi: ruksak; težina ruksaka; učenici osnovne škole.

\section{Uvod}

U nižim razredima osnovne škole (6 - 10 godina života) učenici prolaze vrlo važno tjelesno i razvojno razdoblje (Kellis i Emmanouilidou, 2010). Djeca moraju nositi različite materijale poput knjiga, bilježnica, mapa, boca za vodu, kutijica s hranom, odjeće za tjelesnu kulturu; stoga ih većina nosi ruksak (Abdullah, McDonald i Jaberzadeh, 2012). Loše držanje ističe se kao problem s kojim se djeca i tinejdžeri susreću upravo zbog ruksaka. Različita istraživanja ukazala su na važnost te teme (Drzal-Grabiec, Truszczy'nska, Rykals, Rachwal, Snela i Podg’orska, 2014; Kalaiselvan, 
Kamalakannan i Sowmya, 2016; Paula, Silva i Silva, 2015; Rai i Agarwal, 2014; WalickaCuprys, Skalska-Izdebska, Rachwab i Truszczynsks, 2015). Pravilno nošenje ruksaka vrlo je važno za sprečavanje lošeg držanja tijela. Ako dijete koje svakodnevno mora nositi ruksak to ne čini pravilno, moguće je da će se suočiti s različitim zdravstvenim tegobama, posebice bolovima u donjem dijelu leđa, u leđima i ramenima (Dockrell, Simms i Blake, 2013; Drzal-Grabiec i sur., 2014; Fernandes, Casarotto i Joao, 2008; Ibrahim, 2012; Kistner, Fiebert, Roach i Moore, 2013; Parlak-Demir, Çırak, Dalkılınç, Yllmaz, Uraş i Kömürcü, 2012; Zakeri, Baraz, Gheibizadeh i Saidkhani, 2016). Slično istraživanje pokazalo je da je nepravilno nošenje ruksaka prouzročilo kod 44,6 \%, 21,3 \%, i 63,4 \% djece tegobe u leđima i donjem dijelu leđa, kifozu i lordozu (Parlak-Demir i sur., 2012). Čimbenici povezani sa školom poput dostupnosti ormarića i kurikula, kao i individualni faktori poput djetetova spola, dobi, dijagnoze iskrivljene kralježnice, može povećati rizik od bolova u leđima ili nepravilnoga držanja (Abdullah i sur., 2012; Kellis i Emmanouilidou, 2010; Rai i Agarwal, 2014).

Američka udruga za radnu terapiju (Eng. The American Occupational Therapy Association (AOTA) objavila je izvješće s preporukama kojima je cilj pomoći djeci na način da pravilno nose ruksake i tako izbjegnu zdravstvene tegobe: (1) težina djetetova ruksaka ne bi trebala iznositi više od $10 \%$ djetetove tjelesne težine; (2) ruksaci se ne bi trebali nositi koristeći se samo jednom naramenicom; (3) naramenice i leđa ruksaka trebali bi imati ispunjenje ili viskoelastičnu tkaninu; (4) ruksaci bi trebali biti primjereni dobi djeteta; (5) naramenice bi se trebale namjestiti prema djetetovim leđima; (6) ruksake bi trebao podržavati pojas; (7) ruksaci bi trebali odgovarati veličini leđa; (8) sadržaj bi se trebao nositi u ruci ili na kotačima (torba s kotačima) ako je ruksak pretežak (AOTA, 2013). Međutim, istraživanja o načinu nošenja ruksaka i težine ruksaka ukazuju na rezultate daleko od primjerenih. Različita istraživanja pokazuju da djeca nose ruksake koji su teži od $10 \%$ njihove tjelesne težine (Barkhordari, Ehrampoush, Barkhordari, Derakhshi, Barkhoradri, i Mirzaii, 2013; Dockrell, Blake i Simms, 2016; Cuprys, i sur., 2015; Kalaiselvan i sur., 2016; Paula i sur., 2012; Walicka- Zakeri i sur., 2016). U Turskoj ne postoje istraživanja o načinu nošenja ruksaka i težini ruksaka. Ovo istraživanje pokušat će popuniti tu prazninu i odrediti težinu ruksaka učenika osnovnih škola i način nošenja ruksaka u Turskoj. Istraživanje je zamišljeno kao vodič za praktičare u obrazovanju kako bi kod djece osnovnoškolske dobi osvijestili ispravna postupanja kod nošenja ruksaka.

\section{Metode}

\section{Istraživanje}

Ovo transverzalno deskriptivno istraživanje provedeno je u tri osnovne škole $u$ Ankari u Turskoj tijekom zimskoga semestra 2017. godine. Populaciju su činile sve škole u Altındagu, Ankari, a uzorak dobiven odabranom metodom nasumičnog odabira iz tri sociodemografska sloja društva (niski, srednji, visoki) sastojao se od učenika iz triju škola. Veličina uzorka određena je na minimum od 374 ispitanika 
koristeći se određenim brojem pojedinaca u populaciji poznatim pod nazivom formula za uzorkovanje. Razine su određeni s obzirom na razrede: prvi, drugi, treći i četvrti razred. Upotrebom formule „naziv razine/veličina razine) x veličina uzorka izračunate su sume za stratificirano nasumično uzorkovanje. Broj učenika iz svake razine koji je uvršten u uzorak određen je prema broju učenika u razini i veličini razine (83 učenika iz 1. razreda, 93 učenika iz 2. razreda, 102 iz 3. razreda i 96 učenika iz 4. razreda), a učenici su unutar razine nasumično odabrani. Uzorak se sastojao od 374 učenika kao rezultat stratificirane s- metode uzorkovanja. Istraživanje je provedeno uz pomoć učenika volontera iz odabranih škola u dobi od 6 do 11 godina. Za provedbu istraživanja istraživači su dobili pismena odobrenja roditelja učenika koji sudjeluju $\mathrm{u}$ istraživanju i usmena odobrenja učenika. Odobrenje institucije dobiveno je od Altındag District Directorate of National Education, a etičko odobrenje za provedbu istraživanja dobiveno je (datum 12/25/2018 broj 82413) od Etičkog odbora Sveučilišta Ankara.

\section{Instrument}

U istraživanju se koristio obrazac za osobne podatke koji se sastojao od osam čestica kako bi se dobili podaci o dobi, spolu, razredu, tjelesnoj težini, vrsti ruksaka, načinu nošenja i težini ruksaka, kao i popisu s osam čestica koji je nastao na osnovi preporuka Američke akademije pedijatara (AAP) (2015) i AOTA (2013) vezan uz pravilno nošenje ruksaka. Taj obrazac sadrži čestice koje određuju karakteristike ruksaka i način nošenja ruksaka, a učenici su odgovarali s „da/ne“.

Istraživači su proveli antropometrijska mjerenja u skladu sa standardnim procedurama koje se navode u Baby, Child, and Adolescent Monitoring Protocols turskog ministarstva zdravstva. Istraživači su mjerili tjelesnu težinu djece koristeći se elektroničkim mjeračem težine - vagom (Jowoo-JW-3331) s osjetljivošću do 100 g. Djeca su bila odjevena u standardnu uniformu, ali bez cipela, kako bi mjerenje bilo ujednačeno. Ruksaci su izmjereni upotrebom vage osjetljive na $10 \mathrm{~g}$. Isti mjerni instrument koristio se za sve ispitanike kako bi se standardizirala mjerenja, a podešavanje je rađeno nakon svakog desetog mjerenja. Stopa težine ruksaka u odnosu na težinu tijela izračunata je uz pomoć formule ${ }^{\star} 100 /$ tjelesna težina. Podatke o načinu nošenja ruksaka istraživači su dobili promatranjem djece.

\section{Analiza podataka}

Za obradu i analizu podataka iz istraživanja koristili smo se statističkim paketom za društvene znanosti (SPSS) za Windows 15.0. Statistička značajnost p-vrijednost postavljena je na $<0.05$. U istraživanju je za analizu čestica dob, spol, razred, vrsta ruksaka, način nošenja, težina i status upotrebe primijenjena deskriptivna statistika (broj, postotak, srednja vrijednost, standardna devijacija). Za određivanje promjene u težini ruksaka i odnosu ruksak/težina tijela s obzirom na spol, dob i razred djeteta primijenjen je t-test i ANOVA za nezavisne skupine. 


\section{Rezultati}

Srednja vrijednost za dob ispitanika u uzorku je 8.33 godina (min. 6- max. 11), srednja vrijednost njihove tjelesne težine $29.3 \mathrm{~kg}$. Nešto više od polovine ispitanika $(53,9 \%)$ muškoga su spola. Karakteristike ruksaka i načini nošenja prikazani su u Tablici 1 koja pokazuje da 96,2 \% djece nosi ruksak na obje naramenice, kod 54,2 $\%$ djece ruksaci ne prekrivaju leđa u potpunosti, 42,1 \% nosi ruksak koji visi preko donjeg dijela leđa, a nitko od ispitanika nije upotrebljavao pojas oko struka dok je nosio ruksak. Nitko od djece nije imao pristup školskom ormariću u koji bi mogao odložiti svoje stvari.

Tablica 1

Način nošenja ruksaka - stanje $(N=374)$

\begin{tabular}{|c|c|c|}
\hline \multirow{2}{*}{ Način nošenja ruksaka - stanje kod djece } & $\mathrm{Da}$ & $\mathrm{Ne}$ \\
\hline & $\mathrm{N}(\%)$ & $\mathrm{N}(\%)$ \\
\hline Ruksak ima dvije naramenice. & $345(99,4)$ & $2(0,6)$ \\
\hline Naramenice se mogu namjestiti. & $339(97,7)$ & $8(2,3)$ \\
\hline $\begin{array}{l}\text { Naramenice su velike i sadrže meki umetak ili viskoelastičnu } \\
\text { tkaninu. }\end{array}$ & $181(52,2)$ & $166(47,8)$ \\
\hline $\begin{array}{l}\text { Površina ruksaka koja je u doticaju s leđima ima potporni meki } \\
\text { jastučić ili viskoelastičnu tkaninu. }\end{array}$ & $176(50,7)$ & $171(49,3)$ \\
\hline Postoji remen za struk ili remen za prsa. & - & $347(100,00)$ \\
\hline Dijete se služi remenom oko struka ili oko prsnog koša. & - & $347(100,00)$ \\
\hline Ruksak je napravljen od laganog, ali kvalitetnog materijala. & $149(42,9)$ & $198(57,1)$ \\
\hline $\begin{array}{l}\text { Ruksak nose pričvršćen } 5 \mathrm{~cm} \text { iznad srednjeg dijela leđa s nara- } \\
\text { menicama. }\end{array}$ & $70(20,2)$ & $277(79,8)$ \\
\hline Dijete ne nosi ruksak samo. & $27(7,21)$ & - \\
\hline Dijete ima ormarić u školi. & - & $374(100,00)$ \\
\hline
\end{tabular}

Srednja vrijednost za težinu ruksaka je 4,03 $\mathrm{kg}$ ( $\mathrm{min}, 1,14 \mathrm{~kg}$, max, $8,11 \mathrm{~kg}$ ). Rezultati pokazuju da je odnos težine ruksaka i tjelesne težine između 3,94 \% i 31,13\%, sa srednjom vrijednošću od $14,4 \%$ (Table 2). Velika većina (83,6 \%) djece nosi ruksak teži od $10 \%$ njihove tjelesne težine (vidi Sliku 1). Težina ruksaka povećava se u skladu $s$ dobi $(r=0,233 ; \mathrm{p}<0.01)$ i razredom $(\mathrm{r}=0,333 ; \mathrm{p}<0.01)$ djeteta $(\mathrm{p}<0.01)$. Težina ruksaka i odnos ruksak/težina tijela nisu pokazali razlike s obzirom na spol djeteta (Tablica 2).

\section{Rasprava}

Ovo istraživanje pokazalo je da je srednja vrijednost težine ruksaka za djecu u dobi od šest do jedanaest godina $4,03 \mathrm{~kg}$, odnos ruksak/tjelesna težina je $14,4 \%$ i da većina djece nosi ruksake teže od $10 \%$ njihove tjelesne težine. Slični rezultati dobiveni su i u drugim istraživanjima koja su provedena s učenicima osnovnih škola (Barkhordari i sur. 2013; Dockrell i sur., 2016; Kellis i Emmanouilidiou, 2010; ). U istraživanju koje su proveli Dockrell i sur. (2016) srednja vrijednost težine ruksaka bila je 4,7 kg te 
je dobiveni odnos težine ruksaka/tjelesne težine 12,4 \%; Kellis i Emmanouilidiou (2010) saznali su da je odnos težine ruksaka/tjelesne težine $12,4 \%$. Barkhordari i sur. (2013) utvrdili su da je srednja vrijednost težine ruksaka $4,6 \mathrm{~kg}$, a odnos težine ruksaka/tjelesne težine 12,9\%. Zakeri i sur. (2016) su u svome istraživanju pokazali da težina ruksaka za djecu nije standardizirana. $U$ istom istraživanju pokazalo se da je odnos težine ruksaka/tjelesne težine kod djece bio prilično visok. Jedan od mogućih razloga je da većina državnih škola u Turskoj nema ormariće u kojima djeca mogu odložiti svoje stvari. Stoga djeca u svojim ruksacima svakodnevno moraju nositi knjige i bilježnice. Nadalje, neminovno je da će djeca nositi teške ruksake jer za školu trebaju i dodatne materijale (npr. materijal za likovni, odjeću za tjelesnu i zdravstvenu kulturu, prehranu).

Osnovni standard za nošenje ruksaka je odnos težine ruksaka/tjelesne težine za razliku od same težine ruksaka koja mora biti do maksimalno 10 \% (AOTA, 2013; AAP, 2015). Paula i sur. (2015), Barkhordari i sur. (2013), Zakeri i sur. (2016) i Dockrell i sur. (2016) ustanovili su da 59,06 \%, 56,3\%, 55,1 \%, i 69,3\%, učenika osnovne škole nosi ruksak teži od $10 \%$ njihove tjelesne težine, a Walicka Cuprys i sur. (2015) ustanovili su da 59,63 \% djece u dobi od sedam godina nosi ruksak teži od $10 \%$ njihove tjelesne težine. Kalaiselvan i sur. (2016) tvrde da većina djece u dobi od 11 do 15 godina nosi ruksak čija je težina između $10 \%$ i $18 \%$ njihove tjelesne težine.

Različite studije pokazale su da se djeca suočavaju s bolovima u leđima i ramenima (Ibrahim, 2012; Kistner i sur., 2013.; Paula i sur., 2015; ), deformacijama držanja posebice vrata i leđa (Drzal-Grabiec i sur., 2014; Kalaiselvan i sur., 2016; Paulat i sur., 2015; Rai i Agarwal, 2014), te sve učestalijom pojavom pogrbljenih ramena, kifoze i lordoze (Walicka-Cuprys i sur., 2015; Zakeri i sur., 2016) i križne kosti savijene do uspravnog položaja (Kistner i sur., 2013) kao rezultat nošenja ruksaka koji su teži od 10 $\%$ njihove tjelesne težine. Smanjenje težine koju djeca dnevno nose, promatranje težine ruksaka, te osiguranje ormarića u školama mogući su načini smanjenja spomenutih rizika (Walicka-Cuprys i sur., 2015).

Načini nošenja ruksaka jednako su važan čimbenik za djetetov fizički razvoj kao i težina ruksaka. Rezultati pokazuju da se djeca nisu koristila pojasom dok su nosila ruksak, da ruksaci kod gotovo polovine djece nisu u doticaju s leđima i da ruksaci vise ispod donjeg dijela leđa. Prema Parlak-Demir i sur. (2012) 77,4 \% djece nosi svoje ruksake na obje naramenice i ruksak u potpunosti prekriva leđa. Dockrell i sur. (2016) izjavili su da $85 \%$ djece u osnovnoj školi nosi svoje ruksake na oba ramena. Prema Barkhordari i sur. (2013) 83,4 \% djece nosilo je svoje ruksake na oba ramena, a samo $4 \%$ ruksake je vuklo na kotačima. Paula i sur. (2015) ustanovili su da ruksaci kod 88,3 $\%$ djece u potpunosti prekrivaju leđa, a da njih samo 6,33 \% oko struka ima pojas. Kellis i Emmanouilidou (2010) izjavili su da 89,3 \% djece u dobi od šest do 11 godina nosi ruksak na oba ramena, 6,9 \% ima ruksak na kotačima, a omjer nošenja ruksaka na jednom ramenu povećava se s dobi djeteta. Međutim, u skladu s preporukama o pravilnom nošenju ruksaka, ne samo da bi ruksaci trebali biti nošeni na oba ramena 
nego bi se trebale poduzeti i mjere zaštite poput provjere da ruksaci u potpunosti prekrivaju leđa, donji dio leđa i da se koristi podupirući pojas (AAP, 2015; AOTA, 2013; Rai i Agarwal, 2014). Važno je da se nepravilno nošenje ruksaka ustanovi, da se prati i da se o tome educiraju roditelji i učitelji.

Ovo istraživanje pokazalo je da dječji ruksaci postaju teži s povećanjem njihove dobi i razredom, što je u skladu s istraživanjem koje su proveli Barkhordari i sur. (2013). Broj sati nastave povećava se sa svakim sljedećim razredom i prema tome povećava se i broj materijala koji djeca donose u školu. Međutim, dok je jedno istraživanje pokazalo da se težina ruksaka povećava kako se povećava i dob djeteta (Paula i sur., 2015), drugo je istraživanje pokazalo da su djeca u dobi od šest do osam godina pet puta više sklonija nošenju težih ruksaka od starije djece (Kellis i Emmanouilidou, 2010). Rezultati ovoga istraživanja pokazuju da se načini nošenja ruksaka razlikuju $\mathrm{u}$ odnosu na rezultate prijašnjih istraživanja u drugim zemljama. Pretpostavlja se da je uzrok tome obrazovni sustav, kulturne i zemljopisne razlike. Kako bi edukacija o pravilnom nošenju ruksaka bila učinkovita, ona bi trebala u obzir uzeti kulturne elemente, dinamiku i vrijednosti dotičnog društva.

Ovo istraživanje nije pokazalo statistički značajne razlike između omjera težine ruksaka/tjelesne težine djevojčica i dječaka. Rezultat je to koji pronalazimo i u drugim istraživanjima (Ibrahim, 2012; Kellis i Emmanouilidou, 2010; Paula i sur., 2015). Djevojčice nose iste materijale kao i dječaci, a njihova niža tjelesna masa povećava se $\mathrm{s}$ omjerom težine ruksaka/tjelesne težine.

\section{Zaključak}

Ovo istraživanje provedeno je s ciljem određivanja načina nošenja ruksaka i težine ruksaka kod učenika osnovnih škola. Rezultati su pokazali da je težina ruksaka visoka kao i učestalost nepravilnog nošenje ruksaka. Istraživanje je također pokazalo da je većina djece u istraživanju nosila ruksake koji su teži od $10 \%$ njihove tjelesne težine. Rezultati ukazuju na potrebu uvođenja mjera opreza i organiziranja edukacije vezane uz pravilno nošenje ruksaka kod djece. Ti rezultati daju osnovu za praćenje odnosno zaštitu i poboljšanje zdravstvenoga stanja djeteta, za određivanje potreba i definiranje problema učenika osnovnih škola koji čine velik dio populacijske piramide u Turskoj, kao i za organiziranje edukacija i daljnjih istraživanja vezanih uz taj problem. Neke školske medicinske sestre mogle bi se uključiti u sve navedene usluge. Medicinske sestre u školi redovito se u razvijenim zemljama uključuju u takve programe. Iako su zaduženja školskih medicinskih sestara definirana Pravilnikom o sestrinstvu, medicinske sestre još uvijek se ne zapošljavaju u školama. Zbog toga školske zdravstvene usluge u Turskoj još nisu na željenoj razini. Nužno je imati medicinske sestre u školama da bi se osigurala podrška i da bi se mogao promatrati zdravi razvoj učenika koji predstavljaju većinu populacije u Turskoj. Medicinske sestre također mogu educirati djecu, roditelje i učitelje o pravilnom nošenju ruksaka. Medicinske sestre mogu obaviti i pregled kralježnice sa svrhom rane dijagnoze boli 
i distorzije držanja s kojom se djeca susreću zbog nepravilnog nošenja ruksaka te na taj način prevenirati i reducirati mogući razvoj distorzije u kifozu, lordozu i skoliozu. Pribavljanje osobnih ormarića u školama također bi moglo pridonijeti smanjenju težine ruksaka za djecu te izbjegavanje nošenja nepotrebnih knjiga. Da bi se zaštitilo fizičko zdravlje djeteta, mogu se primijeniti razne prilagodbe poput modificiranja školskog kurikula, tjedne satnice, racionalnih rasporeda koji smanjuju broj knjiga i bilježnica koje djeca moraju nositi u školu.

Na kraju, morali bismo spomenuti i neka ograničenja ovoga istraživanja. Kao prvo, ovo istraživanje provedeno je s djecom u samo tri škole, a kao drugo težina ruksaka mjerena je samo jednom. Daljnja istraživanja trebala bi okupiti veći uzorak, a mjerenje težine ruksaka i mjerenje vremena nošenja ruksaka trebalo bi provesti nekoliko puta.

\section{Potvrda}

Autori izjavljuju da nije bilo sukoba interesa. Isključivo su autori ovoga rada odgovorni za njegov sadržaj i pisanje. 